Research Article

\title{
Biological Impact of Exposure to Extremely Fine-Grained Volcanic Ash
}

\author{
Cristina Aguilera, ${ }^{1}$ Marco Viteri, ${ }^{1}$ Rachid Seqqat $\mathbb{D}^{\mathrm{D}},{ }^{1,2}$ Ligia Ayala Navarrette, ${ }^{1}$ \\ Theofilos Toulkeridis, ${ }^{1}$ Ana Ruano, ${ }^{3}$ and Marbel Torres Arias $\mathbb{D}^{1,2}$ \\ ${ }^{1}$ Departamento de Ciencias de la Vida, Laboratorio de Inmunología y Virología, Universidad de las Fuerzas Armadas ESPE, \\ Av. Gral. Rumiñahui s/n, P.O. Box 171-5-231B, Sangolquí, Ecuador \\ ${ }^{2}$ Centro de Nanociencia y Nanotecnología, Universidad de las Fuerzas Armadas ESPE, Av. Gral. Rumiñahui s/n, \\ P.O. Box 171-5-231B, Sangolquí, Ecuador \\ ${ }^{3}$ National Institute of Public Health Research (INSPI), Quito, Ecuador \\ Correspondence should be addressed to Marbel Torres Arias; mmtorres@espe.edu.ec
}

Received 8 March 2018; Revised 17 May 2018; Accepted 10 June 2018; Published 16 July 2018

Academic Editor: Paresh Chandra Ray

Copyright (c) 2018 Cristina Aguilera et al. This is an open access article distributed under the Creative Commons Attribution License, which permits unrestricted use, distribution, and reproduction in any medium, provided the original work is properly cited.

\begin{abstract}
At the northwestern edge of South America is located Ecuador. This place is a classical example of an active continental margin with widespread active volcanism. Detailed studies about the impact of volcanic ash on human health are still lacking. Therefore, the disease of exposed populations is unknown. The objective of the present investigation was to assess the biological impact of Pichincha volcanic ash on cell culture and inflammation in murine lung tissues that will contribute to the understanding of the hazards. In this study, the in vivo phase was performed in mice C57BL/6 exposed to several doses of volcanic ash $(0.5,1$, and $3.75 \mathrm{mg} / 100 \mathrm{~g}$ mouse body weight). The body weight and survival were controlled during seven days of treatment. The expression of inflammation markers NRLP 3, caspase-1, pro-IL-1, IL-1 $\beta$, IL-6, IL-8, and h-HPRT was analyzed. The in vitro phase was performed in lung cancer cells A549, peritoneal macrophages, and McCoy cells exposing them to different concentrations of volcanic ash $(80,320$, and $1280 \mu \mathrm{g} / \mathrm{cm} 3)$ to determine the cytotoxicity and the production of reactive oxygen species. The ash initiated activation of the inflammasome complex NRLP 3 and the initiation of a proinflammatory activity in the murine lung tissue depending on the concentration of this agent. The viability of A549 and McCoy cell decreased with the length of exposure and increased with the concentration of volcanic ash. The activity in superoxide dismutase decreased by about $60 \%$, leading to the formation of reactive oxygen species. These results associated with compounds contained in Pichincha volcanic ash are considered hazardous elements which induce inflammation leading to activate inflammasome NRLP, releasing reactive oxygen species, and producing changes in cell morphology and density, all of which are expression of cytotoxicity.
\end{abstract}

\section{Introduction}

The Pichincha volcanic complex (PVC) is located on the Western Cordillera of the Ecuadorian Andes, some $11 \mathrm{~km}$ west of the city of Quito. This PVC consists of five successive volcanoes inside of two major volcanic edifices, named Rucu Pichincha and the younger Guagua Pichincha, which have been active since approximately $1.1 \mathrm{Ma}$ ago [1]. The youngest lava dome complex within the Guagua Pichincha volcanic edifice has been active since the Early Holocene, evidenced by a series of eruptive phases within the last 3,000 years, where domes have been formed and collapsed, while eruptions have been from phreatic, vulcanian, and subplinian up to plinian [2]. Ash emissions have been witnessed on various occasions, especially during the volcanic crisis of 1998-2001, when four strong and independent events (on the 05th and 7th of October, 26th of November, and 10th of December of 1999) covered the city of Quito with a mantle of very fine-grained, nanosized, fractured ash particles [2].

As any eruption of a volcano emits ash and gases that contain particulate material of different sizes from nanoscale to microns, the amount released from these particles has 
been able to reach $30 \times 10^{6}$ tons of pyroclastic material represented by ash [3]. Volcanic ash of Guagua Pichincha is a thin material ( $<2 \mathrm{~mm}$ in diameter), and the main products found are dacitic, andesitic, and high-Rb acid [4] including sulfur dioxide, silicon oxide $\left(\mathrm{SiO}_{2}\right)$, and aluminum oxide $\left(\mathrm{Al}_{2} \mathrm{O}_{3}\right)$ [5]. Moreover, volcanic activity is a natural source of respirable nanoparticles. The formation of crystals in volcanic ash is due to the abundance of short-range minerals among the main nanoscale materials, including imogolite (tubular nanotubes), allophane (nanospheres), ferrihydrite, and iron-humic complexes [6].

Previous studies indicated that both particle size and the percentage of crystalline-free silica play a crucial part in the development of respiratory diseases such as silicosis and tuberculosis. In vivo studies have shown that cristobalite present fibrogenicity and may cause silicosis and cancer [7]. Silicosis is caused by the inhalation of crystalline silica particles for extended periods of time. Silica presents different crystalline forms which vary in levels of fibrogenicity according to the degree of crystallization but not with crystalline silica concentration $[8,9]$. Fibrogenicity increases from the less organized crystal structure to the more organized crystal structures of cristobalite [8]. The inhalation of silica can also lead to the development of bronchogenic carcinoma [10].

A recent study indicated an association between chronic exposure to volcanically active environments and the occurrence of DNA damage in human buccal epithelial cells, revealing that noneruptive active volcanism is a risk factor of carcinogenesis [11]. In a further study, when mice have been exposed to volcanogenic air pollution, alveolar space, alveolar perimeter, and lung structural functionality ratio decreased, while their alveolar septal thickness increased [12].

Additionally, the ash is markedly hemolytic, exhibiting an activity like chrysotile asbestos, a known fibrogenic agent. The results of these studies have been taken in conjunction with the results of animal studies indicating a fibrogenic potential of volcanic ash in heavily exposed humans [9]. However, a variety of studies suggest that the volcanic ash may pose a risk for pneumoconiosis in heavily exposed human populations [9].

Furthermore, cristobalite may cause inflammation in the lung and granuloma in the hilar lymph nodes of rats associated with significant size augmentation at 13 weeks postinstillation, while the same mineral induced fibrosis in the lung at 49 weeks postexposure [13]. Besides, ash respirable fractions have been used to investigate the in vitro response of THP-1 and A549 cells in cytotoxicity, cellular stress, and proinflammatory assays associated with toxicity. Macrophages experienced minimal ash-induced cytotoxicity and intracellular reduction of glutathione. However, production of IL- $1 \beta$, IL- 6 , and IL- 8 has been sample dependent. Lung epithelial cells experienced moderate apoptosis, sample-dependent reduction of glutathione, and minimal cytokine production [14].

On the contrary, exposure to $\mathrm{SiO}_{2}$ nanoparticles results in dose-dependent cytotoxicity in cultural human bronchoalveolar carcinoma-derived cells which is closely correlated to increased oxidative stress [15]. Crystallization plays a role in fibrogenicity, and the large surface area per mass of silica nanoparticles allows for a greater production of reactive oxygen species [10]. The fine-grained character of volcanic ash generated in the long-lived eruption raises the issue of its possible health hazards. Surface- and free-radical production has been closely linked to bioreactivity of dusts within the lung. Concentrations of hydroxyl radicals ( $\left.\mathrm{HO}^{\circ}\right)$ in respirable ash are two to three times higher than a toxic quartz standard [16]. One investigation indicated that in vitro exposure to volcanic ash had little effect on the $\mathrm{O}_{2}$ consumption of rabbit type II cells [17]. The toxic effect has been discovered after both in vitro and in vivo exposure and has not been due to a soluble component of the ash. This implies that inhalation of volcanic ash may adversely affect alveolar macrophages. Therefore, inhibition of superoxide release by volcanic ash may interfere with the ability of alveolar macrophages to protect the lung from some types of respiratory infections [17].

In Ecuador, published data on the effects on human health in the face of the exposure of volcanic ash are rare. Therefore, the main aim of this study was to assess the biological impact of the Pichincha volcanic ash, which certainly will be able to contribute significantly to the understanding of the hazards on cell cultures and inflammation in murine lung tissues. Such data will allow an extrapolation towards the affected populations during exposure to this agent.

\section{Materials and Methods}

2.1. Volcanic Ash Sample. Volcanic ash sample was collected from one of the two strongest eruptions of the PVC of the last 300 years on the 5 th of October 1999. The health hazards of this eruption was previously documented [18], while the physical and chemical analyses of the sample used here have been analyzed in the same detailed way as other volcanic ashes of Ecuador [19-22]. In these studies, the volcanic ash has been dried, sedimented, and stored in undisturbed containers at a temperature of $18^{\circ} \mathrm{C}$ until being processed.

2.2. Sample Preparation. The dry volcanic ash samples were suspended in the appropriate cell-line media and sonicated with heating $\left(37^{\circ} \mathrm{C}\right)$ for one hour to disaggregate the particles.

2.3. Animals Experiment. C57BL/6 mice from 12 to 14 weeks of age were obtained from the National Institute of Public Health Research (INSPI), where they have been housed in an environmentally controlled room (temperature: $22 \pm 3^{\circ} \mathrm{C}$, relative humidity: $30 \pm 10 \%$, programmed ventilation, and $12: 12 \mathrm{~h}$ light-dark cycle). The volcanic ash was weighed, sonicated, and diluted in PBS for the administration of the mice, in such way that the applied concentrations were $0.5,1$, and $3.75 \mathrm{mg} / 100 \mathrm{~g}$ of corporal weight. These concentrations of volcanic ash were taken from related studies [23]. The control group administered PBS.

A total of thirty mice were treated to which intraperitoneal anesthesia was applied with Dormi-Xyl ${ }^{\circledR} 2$ 
TABle 1: Designed primers for inflammation study.

\begin{tabular}{lcc}
\hline Protein & Primer forward and reverse & Product length \\
\hline NLRP3 & $\begin{array}{c}\text { Forward: TCTGCACCCGGACTGTAAAC } \\
\text { Reverse: TTCCGAAGGCTGTGGTTGTG }\end{array}$ & 111 \\
\hline Caspase-1 & $\begin{array}{c}\text { Forward: GGAGATGGTGAAAGAGGTGAA } \\
\text { Reverse: GGTGTTGAAGAGCAGAAAGCA }\end{array}$ & 375 \\
\hline Pro-IL-1 & $\begin{array}{c}\text { Forward: GTCGGGAGGAGACGACTCTAA } \\
\text { Reverse: GCAACTCCTTCAGCAACACG }\end{array}$ \\
\hline IL-8 & $\begin{array}{c}\text { Forward: GGCAAACGAAAATGTGGATGGG } \\
\text { Reverse: TCAGAACGTGGCGGTATCTCT }\end{array}$ \\
\hline IL-1 $\beta$ & $\begin{array}{c}\text { Forward: ACAACAAAAAAGCCTCGTGCTGTC } \\
\text { Reverse: ACAGGTATTTTGTCGTTGCTTGG }\end{array}$ \\
\hline IL-6 & $\begin{array}{l}\text { Forward: TCACAGAAGGAGTGGCTAAGGA } \\
\text { Reverse: AGTGAGGAATGTCCACAAACTGA }\end{array}$ \\
\hline h-HPRT & $\begin{array}{c}\text { Forward: TCAGTCAACGGGGGACATAAAAG } \\
\text { Reverse: GCTTAACCAGGGAAAGCAAAG }\end{array}$ \\
\hline
\end{tabular}

(Agrovet Market Animal Health-30 mL); $0.15 \mathrm{~mL} / \mathrm{kg}$ of mouse and a single dose via transtracheal of $100 \mu \mathrm{L}$ of the ash diluted in PBS was administered and $100 \mu \mathrm{L}$ PBS for the control group. On day 7, after exposure to volcanic ash, the mice were euthanized by cervical dislocation, and then each mouse was excised, the lungs were weighed, and stored at $-80^{\circ} \mathrm{C}$ for RNA extraction from the protocol suggested by Chomzynski and Sacchi [24]. The positive control group was injected by a single dose of lipopolysaccharide (LPS, from E. coli at L2630-25MG).

2.3.1. Cytokine Release. The inflammatory response has been studied by cytokines released from the murine lungs exposed to volcanic ash via real-time PCR (CFX96 real-time system, Bio-Rad) according to the manufacturer's protocol. The applied analysis method for the results is the double delta $C_{t}\left(\Delta \Delta C_{t}\right)$. The endogenous gene selected was h-HPRT. The primers used in the amplification of the genetic expression were designed through the online program primer 3 (http://bioinfo.ut.ee/primer3-0.4.0/) based on sequences published on NCBI (National Center for Biotechnology Information) Table 1.

2.4. Cell Culture Experiment. McCoy, mice fibroblast cell line, and A549 a human adenocarcinoma-derived type II alveolar epithelial cell line were maintained in continuous culture in EMEM growth media and Ham's F-12K (Kaighn's) growth media, respectively, with $10 \%$ of FBS and supplemented with penicillin (100 units. $\mathrm{ml}^{-1}$ ) and streptomycin $\left(100 \mathrm{mg} \cdot \mathrm{ml}^{-1}\right)$. To prepare cells for particle treatment, cells were trypsinized using a $0.25 \%$ Tris-EDTA solution and allowed to readhere overnight. Treatments were performed on $100 \mu \mathrm{l}$ of cells at a density of $1 \times 10^{5}$ cells $\cdot \mathrm{mL}^{-1}$ in each well of a 96-well plate. Both cell lines were maintained at $37^{\circ} \mathrm{C}$, in a $5 \% \mathrm{CO}_{2}$ environment.

Murine peritoneal macrophages were collected in the RPMI medium from the peritoneal cavity. In vitro adhesion of macrophages was maintained in continuous culture in RPMI growth media with $10 \%$ of FBS supplemented with penicillin (100 units $\cdot \mathrm{ml}^{-1}$ ) and streptomycin $\left(100 \mathrm{mg} \cdot \mathrm{ml}^{-1}\right)$. Treatment was performed on $1 \mathrm{~mL}$ of cells at a density of $5 \times 10^{5}$ cells $\cdot \mathrm{mL}^{-1}$ in each well of a 24 -well plate, while cells were maintained at $37^{\circ} \mathrm{C}$ in a $5 \% \mathrm{CO}_{2}$ environment.

Cells were treated for $24 \mathrm{~h}$ with five concentrations of volcanic ash and control particles: 80, 160, 320, 640, and $1280 \mu \mathrm{g} \cdot \mathrm{mL}^{-1}$, and positive control oxide of titanium $\mathrm{TiO}_{2}$ $\left(400 \mu \mathrm{g} \cdot \mathrm{mL}^{-1}\right)$ reported elsewhere [25]. Oxidative stress was assessed by releasing NO (nitrogen oxide) using the Griess test and superoxide dismutase assay to evaluate anion superoxide.

2.4.1. Cytotoxicity Test. Volcanic ash at the final mineral concentrations of 80,320 , and $1280 \mu \mathrm{g} / \mathrm{cm}^{3}$ was added to McCoy and A549 monolayer cells cultures. MTT assay was performed at 72, 120, 168, and 240 hours after volcanic ash particles application. For this purpose, MTT solution was prepared at $1 \mathrm{mg} / \mathrm{ml}$ in $100 \%$ acetone. Then, $10 \mu \mathrm{l}$ of MTT plus $100 \mu \mathrm{l}$ of cell-line media was added to each well. Cells were incubated for 4 hours at $37^{\circ} \mathrm{C}$ with $5 \% \mathrm{CO}_{2}$. After 4 hours, the MTT solution was removed and replaced with $100 \mu \mathrm{l}$ of DMSO. The plate was further incubated for $3 \mathrm{~min}$ at room temperature, and the optical density (OD) of the wells has been determined using a plate reader (Thermo Fisher) at a test wavelength of $570 \mathrm{~nm}$.

Titanium oxide was used as a positive control, and its toxicity is well established in reported studies [7, 25-29].

\subsubsection{Reactive Oxygen Species (ROS)}

(1) Griess Test. The extent of cellular stress was determined by the Griess test, which was used to determine the quantity of nitrite oxide (NO) released in the cell supernatants. Treatment was performed on $1 \mathrm{~mL}$ of McCoy and A549 cells at a density of $2.5 \times 10^{5}$ cells $\cdot \mathrm{mL}^{-1}$ in each well of a 24 -well plate and $1 \mathrm{~mL}$ of murine peritoneal macrophages at a density of $5 \times 10^{5}$ cells $\cdot \mathrm{mL}^{-1}$ in each well of a 24 -well plate. Cells were maintained at $37^{\circ} \mathrm{C}$ in a $5 \% \mathrm{CO}_{2}$ environment.

Volcanic ash at the final mineral concentrations of 80 , 320 , and $1280 \mu \mathrm{g} / \mathrm{cm}^{3}$ was added to McCoy, A549 monolayer 
cells cultures, and macrophages. After 24 and 144 hours with volcanic ash particles, the supernatant of each well was collected. Murine peritoneal macrophages were exposed only 24 hours. The Griess assay was performed with sulfanilamide solution and $N$-1-naphthylethylenediamine dihydrochloride (NED) solution at 1:1 dilution. Then, $100 \mu \mathrm{l}$ of this dilution plus $100 \mu \mathrm{l}$ of cell supernatant was added to each well of a 96-well plate. The microplate was incubated for 30 minutes in the dark at room temperature, and the optical density of the wells was determined using a plate reader at a test wavelength of $540 \mathrm{~nm}$.

The titanium oxide $\left(\mathrm{TiO}_{2}\right)$ at a final concentration of $400 \mu \mathrm{g} / \mathrm{cm}^{3}$ and hydrogen peroxide (3\%) were used as positive controls.

(2) SOD Activity. Treatment was performed on $1 \mathrm{~mL}$ of McCoy and A549 cells each one at a density of $2.5 \times 10^{5}$ cells $\cdot \mathrm{mL}^{-1}$ in each well of a 24 -well plate and $1 \mathrm{~mL}$ of murine peritoneal macrophages at a density of $5 \times 10^{5}$ cells $\cdot \mathrm{mL}^{-1}$ in each well of a 24 -well plate. Cells were maintained at $37^{\circ} \mathrm{C}$ in a $5 \% \mathrm{CO}_{2}$ environment.

Volcanic ash at the final mineral concentrations of 80 , 320 , and $1280 \mu \mathrm{g} / \mathrm{cm}^{3}$ was added to McCoy and A549 monolayer cells cultures individually. Macrophages were exposed to concentrations of $80,160,320,640$, and $1280 \mu \mathrm{g} / \mathrm{mL}$ of volcanic ash. After 24 and 144 hours, the supernatant was collected from each well. Murine peritoneal macrophages were exposed only 24 hours. The superoxide dismutase (SOD) activity was assessed in the fresh supernatant of the cell cultures with a SOD determination kit (Sigma-Aldrich). The microplate was incubated at $37^{\circ} \mathrm{C}$ for 20 minutes, and the absorbance read at $450 \mathrm{~nm}$.

The SOD activity was calculated as follows:

SOD activity (inhibition rate \%)

$$
=\left\{\frac{\left[\left(A_{\text {blank }}-A_{\text {blank3 }}\right)-\left(A_{\text {sample }}-A_{\text {blank2 }}\right)\right]}{\left(A_{\text {blank1 }}-A_{\text {blank3 }}\right)}\right\} * 100 .
$$

The negative control was the culture cells without any exposition. The titanium oxide $\left(\mathrm{TiO}_{2}\right)$ at a final concentration of $400 \mu \mathrm{g} / \mathrm{mL}$ and hydrogen peroxide (3\%) were used as positive controls.

2.5. Statistical Analysis. Statistical analysis has been performed using GraphPad PRISM 6 software (San Diego, CA). The comparisons were conducted using Student's $t$-test and one-way analysis of variance (ANOVA) with the Dunnett and Sidak posttest where appropriate.

\section{Results and Discussion}

3.1. Volcanic Ash Characterization. The photographs taken with SEM indicate the presence of pumice rock (central rounded particle) as result of a very violent magmatic explosion, surrounded by fragmented volcanic glass and some minor minerals such as quartz and plagioclase (Figure 1(a)).
Moreover, Figure 1(b) is a typical angular-shaped plagioclase (big grain), as well as quartz (above grain) and surrounding fresh (un-reworked) volcanic glass. Figure 1(c) illustrates the diameter particle histogram obtained from the analysis of the sample, using the MIRA3 SEM software. We have calculated the size distribution of the particles from manual diameter determination over a 1000 particles.

Table 2 represents the chemical compositions by energy dispersive spectroscopy (EDS) performed on some one hundred ash particles revealed on average typical geochemical ratios known of andesites and dacites of the region with $\mathrm{Al} / \mathrm{Mg}$ of $9.85, \mathrm{Si} / \mathrm{Mg}$ of 24.97, and $\mathrm{Na} / \mathrm{Al}$ ratios of about 0.29 , with a sigma mean error between 0.26 and 0.97 , pending of the particular element.

\subsection{Effect of Volcanic Ash on Mice Body Weight and Survival.} Mice were once inoculated via transtracheal with a $100 \mu \mathrm{L}$ solution of volcanic ash and PBS at a final mineral concentration of $0.5 \mathrm{mg}, 1 \mathrm{mg}$, and $3.75 \mathrm{mg}$ per $100 \mathrm{~g}$ of body weight. Body weight has been recorded on day seven postinfection. Mice exposed to a concentration of volcanic ash of $3.75 \mathrm{mg}$ indicate a constant and significant weight loss on day 7. Mice infected with 0.5 and $1 \mathrm{mg}$ of volcanic ash gained weight as did in the uninfected group postinfection (Figure 2(a)). Likewise, during the exposure of the animals to the volcanic ash, the weight of the food that each group of mice consumed was recorded, demonstrating a reduction in the quantity of food consumed by the animal treated with volcanic ash.

Seven days after infection, all animals exposed to volcanic ash did not entirely die. In contrast, all animals not infected or infected with LPS survived for a 7-day period. Nevertheless, the groups that received the highest concentrations of ash 1 and $3.75 \mathrm{mg}$ perished by 25\% (Figure 2(b)).

The volcanic ash concentrations could overt toxicity as indicated by a change in body weight from animals exposed to $3.75 \mathrm{mg}$, which has often been an indicator of overt or systemic toxicity [30]. In the current study, we observed $25 \%$ of mouse mortality in the groups which have been exposed to highest concentrations of volcanic ash 1 and $3.75 \mathrm{mg}$ (Figure 2(b)). The statistical reduction of body weights in the exposed group of $3.75 \mathrm{mg}$ of volcanic ash indicated a level of malaise, which indicates that volcanic ash may interfere in the welfare and homeostasis of the murine organism [31].

\subsection{Volcanic Ash Induce Expression of Inflammatory Factors} in Mice Lung. Volcanic eruptions increase concern about the potential adverse effects of volcanic ash in the lung [32]. The results from studies in laboratories suggest that volcanic ash is moderately toxic and has the potential to cause fibrosis in the lung of rodents when inhaled in high doses [33].

The term inflammasome is used to define the activation of caspase- 1 characteristic of innate immunity and represents the response directed to suppress pathogenic microorganisms and to avoid tissue damage [34]. It is composed of the receptor with oligomerization domain and nucleotide binding (NLR3), ASC (apoptosis-associated speck-like) protein, and caspase-1. NRLP 3 inflammasome is the only 


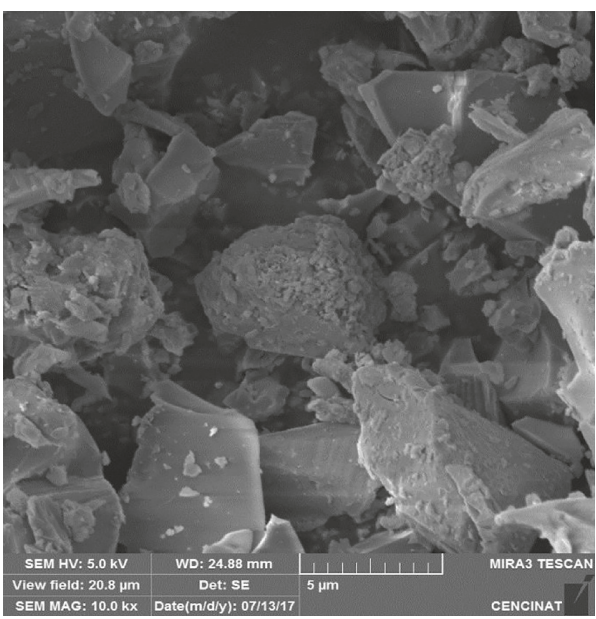

(a)

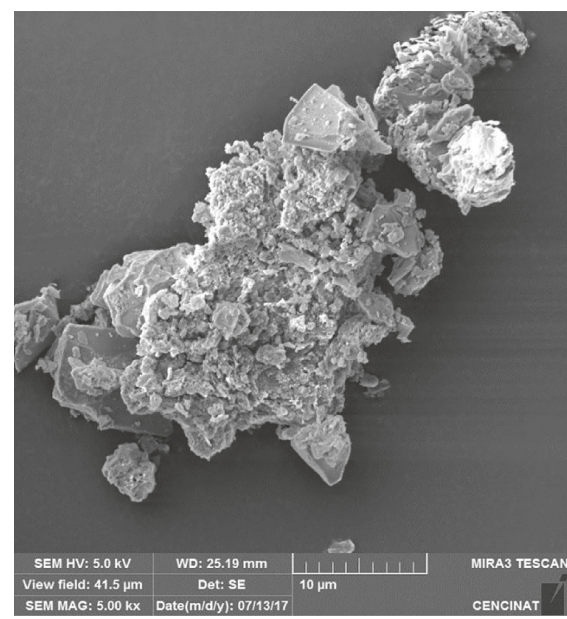

(b)

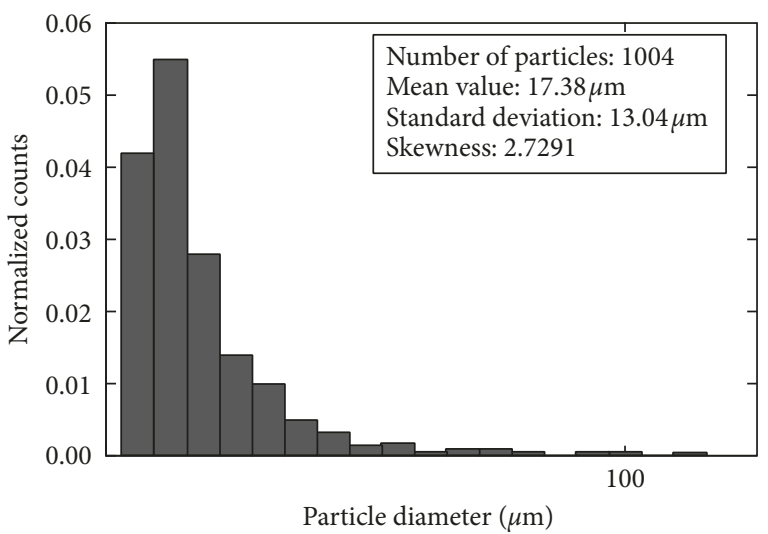

(c)

FIGURE 1: Representative SEM image of Pichincha's volcanic ash: (a) at 10000x magnifications; (b) at 5000 magnifications. The images illustrate angular- and round-shaped particles. (c) Granulometry of fine-grained volcanic ash of the 5th of October 1999 eruption of the PVC, using the MIRA3 SEM software based on 1004 particles.

TABLE 2: Chemical composition expressed as mass percent of major elements of 100 ash particles from the ash samples of the 5 th of October 1999 eruption of the PVC (see Table S1 for details).

\begin{tabular}{lccccccccccc}
\hline Element & $\mathrm{Na}$ & $\mathrm{Mg}$ & $\mathrm{Al}$ & $\mathrm{Si}$ & $\mathrm{P}$ & $\mathrm{S}$ & $\mathrm{K}$ & $\mathrm{Ca}$ & $\mathrm{Ti}$ & $\mathrm{Mn}$ & $\mathrm{Fe}$ \\
\hline Mean value & 5.07 & 1.76 & 17.29 & 43.83 & 1.52 & 2.42 & 5.11 & 10.02 & 2.34 & 0.16 & 10.49 \\
Sigma & 2.60 & 3.08 & 4.95 & 9.67 & 1.26 & 4.48 & 2.63 & 5.72 & 7.62 & 0.16 & 10.65 \\
Sigma mean & 0.26 & 0.31 & 0.49 & 0.97 & 0.13 & 0.45 & 0.26 & 0.57 & 0.76 & 0.02 & 1.06 \\
\hline
\end{tabular}

one activated by several stimuli like molecule effectors produced or released by the mitochondria such as reactive mitochondrial oxygen species, mitochondrial DNA, and cardiolipin phospholipid [35]. The NLRP3 inflammasome is a signaling complex that activates procaspase- 1 and induces the processing of caspase-1-dependent inflammatory cytokines (particularly IL-1 and IL-18) [36]. This inflammasome has been found in cells of the innate immune system such as macrophages and dendritic cells and has been able to be activated in response to a variety of intrinsic factors of the host, as well as a significant number of environmental substances such as silica, asbestos, and hydroxide adjuvant of aluminum [37]. Mice exposed to $0.5,1$, and $3.75 \mathrm{mg}$ of Pichincha's ash produced more NRLP 3 than the untreated control (Figure 3(a)).
The mechanisms of activation of caspase- 1 that triggers different types of inflammasomes are diverse and leads to the induction and secretion of IL- $1 \beta$, generating inflammation and cell death of the proptosis type [38]. Caspases are proteins with cysteine-protease activity, which hydrolyzes in specific aspartate residues, and some of them are involved in inflammatory processes such as caspases 1 , 2, 5, and 12 [39]. The inflammatory response in murine pulmonary tissue has been sampled and was determined to be cytokine dependent. The highest dose $(3.75 \mathrm{mg})$ of volcanic ash resulted in the production of caspase- 1 above threefold in the untreated control (Figure 3(b)), as observed by Lee et al. [40] where the mechanism that governs the expression of caspase- 1 is determined and indicates the 


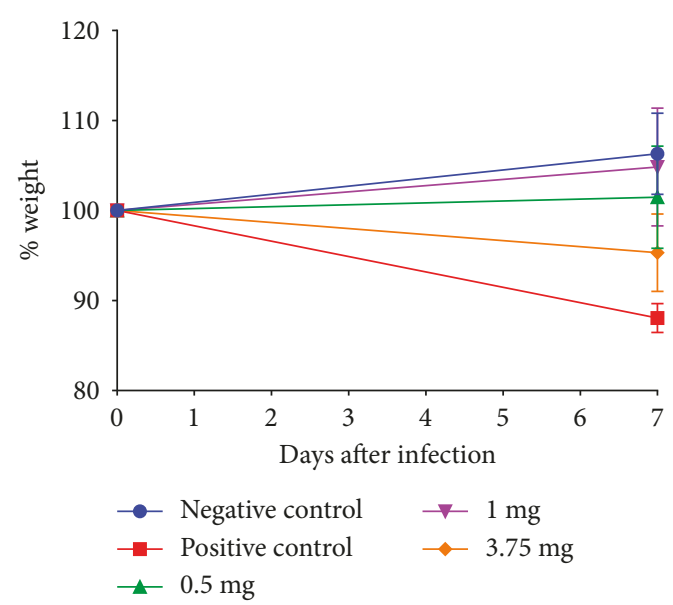

(a)

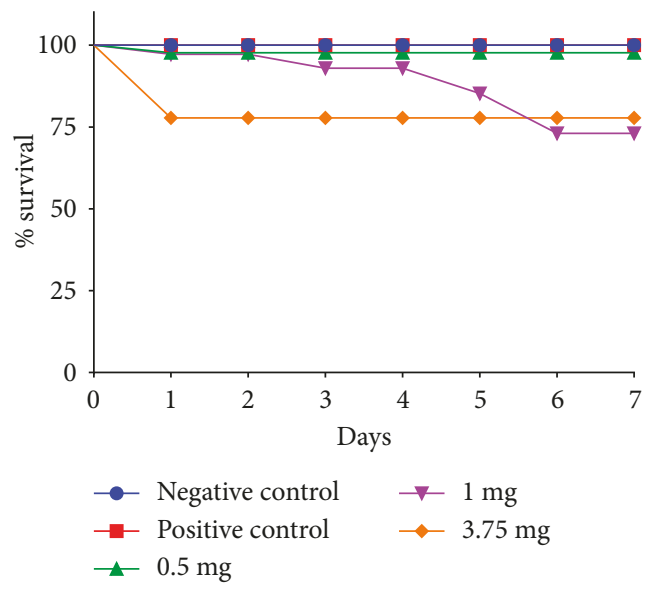

(b)

FIGURE 2: Graph of weight change and survival in infected mice: (a) graphic representation of the body weight (g) of C57BL/6 mice after 7 days postinfection with volcanic ash at concentrations of $0.5 \mathrm{mg}$ (green), $1 \mathrm{mg}$ (purple), and $3.75 \mathrm{mg}$ (orange); negative control (PBS, blue); and positive control (LPS, red). (b) Five groups of mice were uninfected (blue) and infected with volcanic ash at concentrations of $0.5 \mathrm{mg}$ (green), $1 \mathrm{mg}$ (purple), and $3.75 \mathrm{mg}$ (orange) of volcanic ash or intraperitoneally infected with LPS (red), and survival were monitored daily for seven days. All data points for mice not infected or infected with LPS are in the same horizontal line.

hypothesis that the simple increase in caspase-1 levels is sufficient to induce inflammation.

Cytokine pro-IL-1 is produced by macrophages and monocytes as well as nonimmunological cells, such as fibroblasts and activated endothelial cells during cell injury, infection, invasion, and inflammation. IL- $1 \beta$ is synthesized as a precursor protein (pro-IL-1 $\beta$ ), which is not secreted in the active form until it is metabolized by the enzyme caspase1 [35]. Levels for the highest dose (3.75 and $1 \mathrm{mg}$ ) of volcanic ash have been greater than that induced by the inflammation produced by lipopolysaccharide (LPS) in pro-IL-1 released.

IL-1 is a key cytokine in diverse responses of the immune system, and once it is secreted, it participates in the generation of local and systemic immune response against diverse classes of pathogens, and its implication in the pathophysiology of diverse inflammatory diseases highlights its role in the evolution of an inflammatory process [41]. Mice injected with lipopolysaccharide (LPS) present an expression $>10$ times more than the negative control. Although exposed groups to volcanic ash lack significant expression, the release of IL- $1 \beta$ is greater and concentration dependent.

IL-6 is a proinflammatory cytokine that generates the maturity and activation of neutrophils, the maturation of macrophages, and the differentiation/maintenance of cytotoxic T lymphocytes and natural killer cells [35]. To identify an inflammatory response induced by the ash of PVC, the gene expression of the proinflammatory cytokine (IL-6) was measured in the murine lung tissues after treatment (Figure 3(e)). The secretion of the proinflammatory cytokine (IL-6) increased in a dose-dependent manner of volcanic ash as reported in the study of Park et al. [23].

Interleukin-8 (IL-8) has been identified as a chemotactic and leukocyte activating factor produced by activated tissue cells, as well as monocytes/macrophages. IL- $1 \beta$ or IL-12 causes the production and release of IL-8 from neutrophils in the presence of LPS [42]. In a study reported earlier [43], the amounts of protein in IL-1b or IL-12 have been correlated with the amounts of chemokine or with the number of neutrophils, suggesting that the increase in IL-12 and IL$1 \beta$ leads to the increase in chemokine followed by neutrophilic inflammation. Figure 3(f) demonstrates that the volcanic ash at high concentrations ( 1 and $3.75 \mathrm{mg}$ ) induce a significant increase of the inflammatory marker IL-8 over the control.

3.4. Cell Morphology Modification after Volcanic Ash Exposition. The changes in cellular morphology have been considered as a direct indicator of cytotoxicity [16]. This is directly reflected in cell viability, cell mechanisms, and cellular morphology [44]. We examined the morphology of A549 and McCoy cells exposed to different ash particle concentrations for 72 hours by optical microscopy. Cell proliferation is significantly reduced, and morphology shows irregular shape when increasing the ash concentrations (Figure 4). Duan et al. [44] observed that $\mathrm{SiO}_{2}$ produces irregular shape in epithelial cells and density reduction at 24 hours of exposition which is directly reflecting cell injuries. These data indicate the big capacity of silica to be levels of mutagenicity which could contribute too many chronic pulmonary diseases. The deposition of nanoparticles in the lung could lead to chronic inflammation, epithelial injury, and pulmonary fibrosis [45].

A marked vacuolization and ash particles adhered or internalization in the cytoplasm have been observed after the ash treatment of peritoneal macrophages (Figure 5) in A549 cells and McCoy cells with $320 \mu \mathrm{g} / \mathrm{cm}^{3}$ for 24 hours. Voicu et al. [46] observed a vacuolization in human lung fibroblast exposed to $\mathrm{SiO}_{2}$ nanoparticles (NPs) after 24 hours exposure. Moreover, Duan et al. [44] observed in TEM that silica NPs have been internalized into endothelial cells after 24 


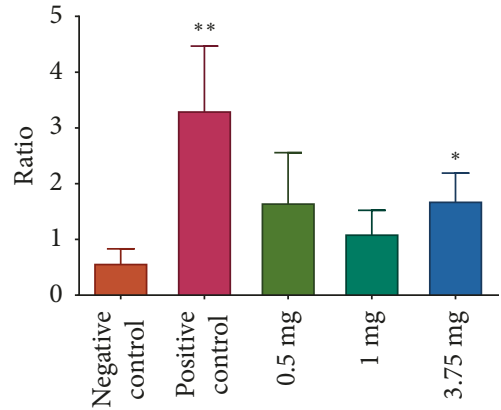

(a)

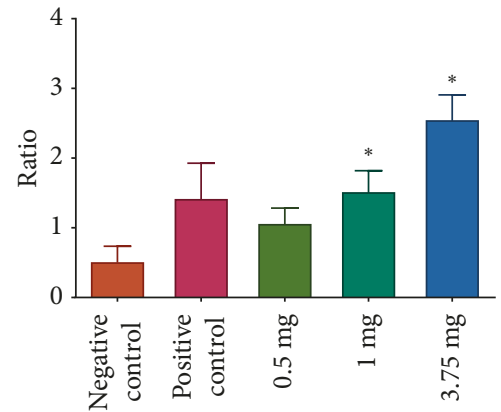

(c)

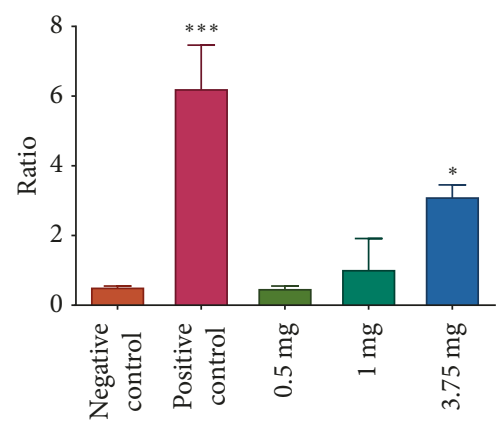

(e)

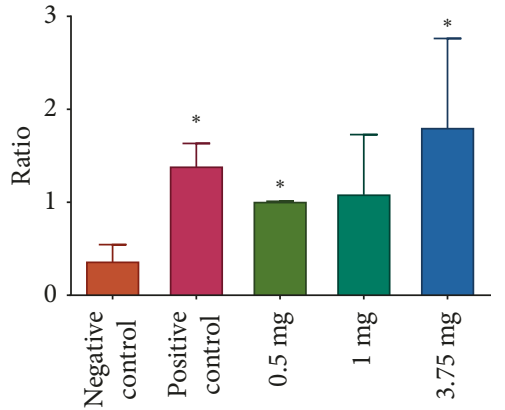

(b)

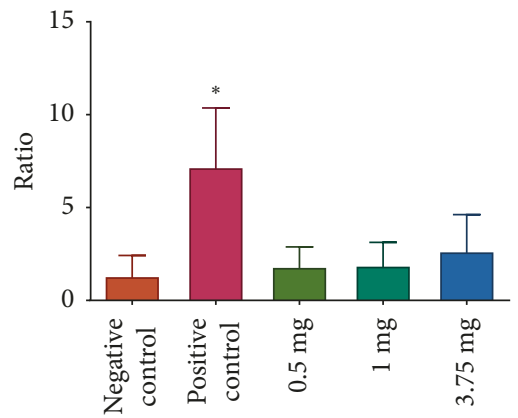

(d)

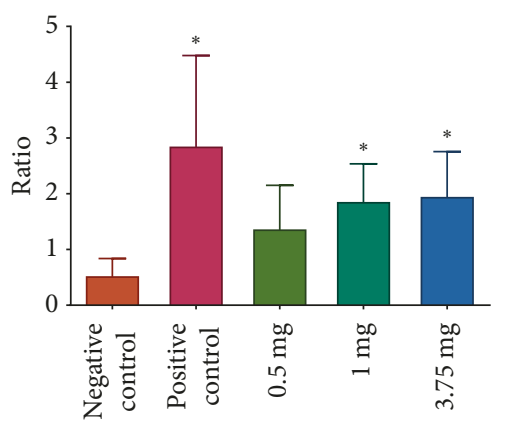

(f)

Figure 3: Cytokine production by C57BL/6 mice exposed to Pichincha's volcanic ash: production of the inflammatory markers (a) NRLP 3 , (b) caspase I, (c) pro-IL-1, (d) IL- $1 \beta$, (e) IL-6, and (f) IL-8 at 7 days after treatment with $0.5,1$, and $3.75 \mathrm{mg} / 100 \mathrm{~g}$ body weights. ${ }^{*} p<0.05$, ${ }^{* *} p<0.01$, and ${ }^{* * *} p<0.001$ (Student's $t$-test).

hours. Additionally, previous study confirmed that the silica nanoparticles may be internalized into the cells and dispersed in the cytoplasm and inside the mitochondria [47]. In rat alveolar epithelial cells exposed to volcanic ash in culture, Monick et al. [48] observed with SEM and TEM ash particles on the cell surface, while in human alveolar macrophages exposed to volcanic ash, ash particles adhered to the surface or were internalized by alveolar macrophages and vesicles within the cell at cytosol.

3.5. Volcanic Ash Induce Cell Cytotoxicity In Vitro. The MTT assay which provides an indication of mitochondrial activity and cell viability [49] indicates the volcanic ash cytotoxicity. A549 and McCoy cells demonstrated a significant reduction in cell viability in response to the duration of exposure and volcanic ash concentration (Figure 6). In both cases, cells presented a decrease in viability at a concentration of 320 and $1280 \mu \mathrm{g} / \mathrm{cm}^{3}$ to 72 hours from 240 hours. The same occurred with the positive control, titanium oxide (Figures 6(a) and 6(b)). These data are comparable with another study where A549 cells were exposed for 24 hours to three different respirable ash particles and titanium oxide from Soufrière Hills [9]. As well, Lin et al. [15] demonstrated that $\mathrm{SiO}_{2}$ reduces A549 cellular viability in a dose- and timedependent manner. On the contrary, human lung fibroblasts have been exposed to different concentrations of $\mathrm{SiO}_{2} \mathrm{NPs}$ which demonstrated a decrease in a time- and dosedependent manner [46].

\subsection{Volcanic Ash Effect on the Reactive Oxygen Species Production in the Cells}

3.6.1. Nitric Oxide. Nitric oxide synthase (NOS) is the enzyme responsible for generation of nitric oxide (NO), a fundamental mediator molecule produced by a variety of 


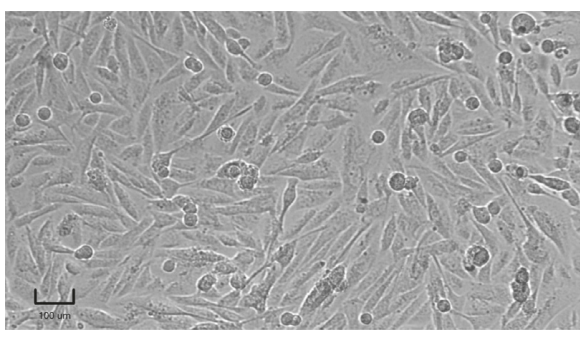

(a)

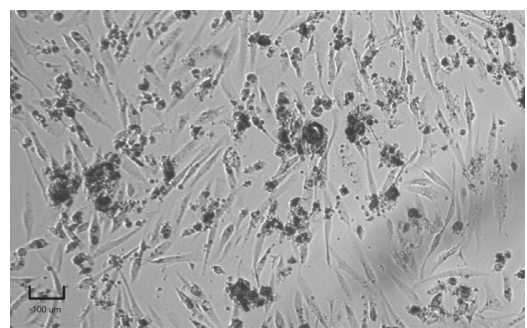

(c)

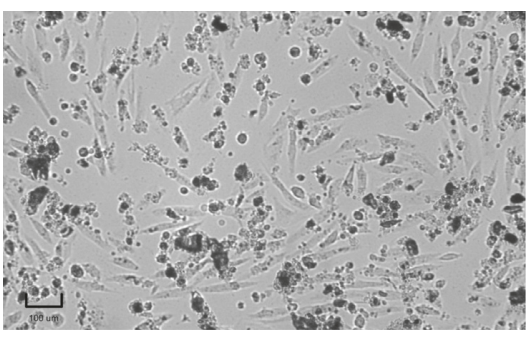

(b)

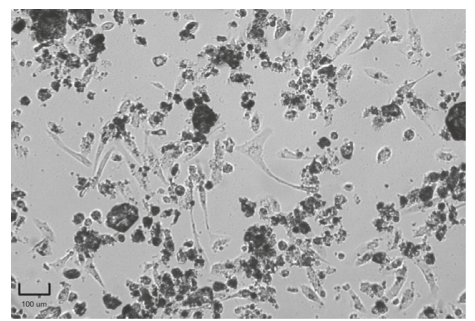

(d)

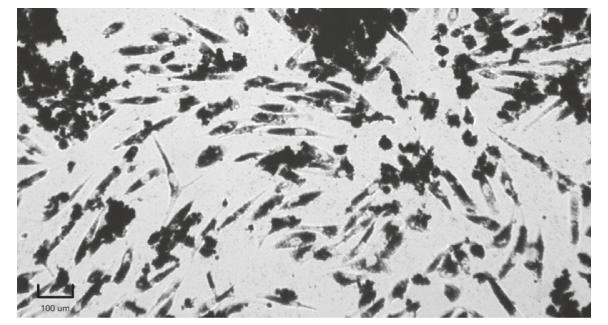

(e)

Figure 4: Morphology of A549 cells with different ash concentrations: (a) cells; (b) cells with $80 \mu \mathrm{g} / \mathrm{cm}^{3}$; (c) cells with $320 \mu \mathrm{g} / \mathrm{cm}^{3}$; (d) cells with $1280 \mu \mathrm{g} / \mathrm{cm}^{3}$; (e) cells with titanium oxide $\left(\mathrm{TiO}_{2}\right.$, positive control). Images are representative of all samples. Scale: $100 \mu \mathrm{m}$.

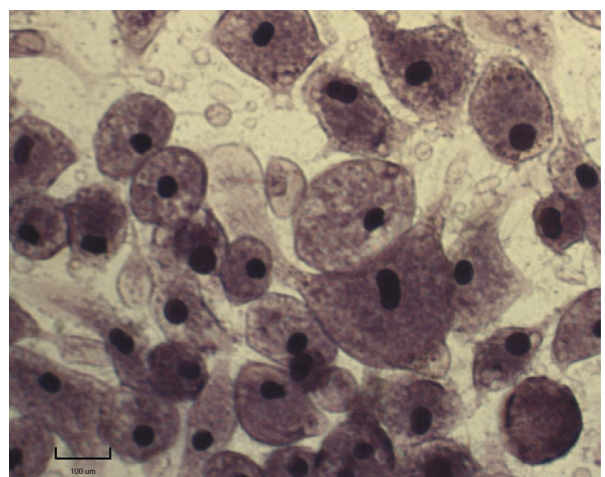

(a)

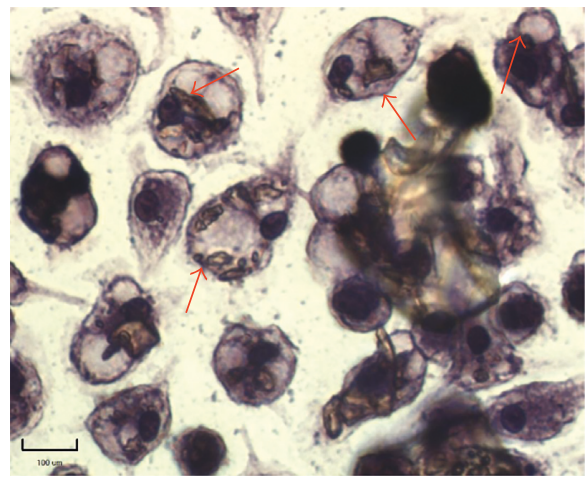

(b)

FIGURE 5: Uptake of ash and vacuolization by peritoneal macrophages: (a) untreated cells and (b) cells treated with $320 \mu \mathrm{g} / \mathrm{cm}^{3}$ and view of cells with internalized and vacuolization of ash particles (arrows). Images are representative of all samples. Staining: hematoxylin and eosin. Scale: $100 \mu \mathrm{m}$.

diverse cell types. Three distinct NOS enzymes have been identified, being the neuronal form (nNOS), the endothelial (eNOS), and the macrophage forms (iNOS). The brain and endothelial forms are constitutive products, while macrophage NOS is present after induction by endotoxins. However, inducible NOS is also upregulated in various types of inflammatory disease, and the NO generated by the enzyme mediates various symptoms of inflammation $[50,51]$.
A549, McCoy cells, and peritoneal macrophages have been treated with concentrations of 80, 320, and $1280 \mu \mathrm{g} / \mathrm{cm}^{3}$ of volcanic ash for 24 hours. The absorbance of nitric oxide in the spent medium has been determined using the Griess test. The results yielded in peritoneal macrophages an increase in NO absorbance with different ash concentrations, with a statistically significant increase at the ash concentration $320 \mu \mathrm{g} / \mathrm{cm}^{3}$ compared to cells without any 


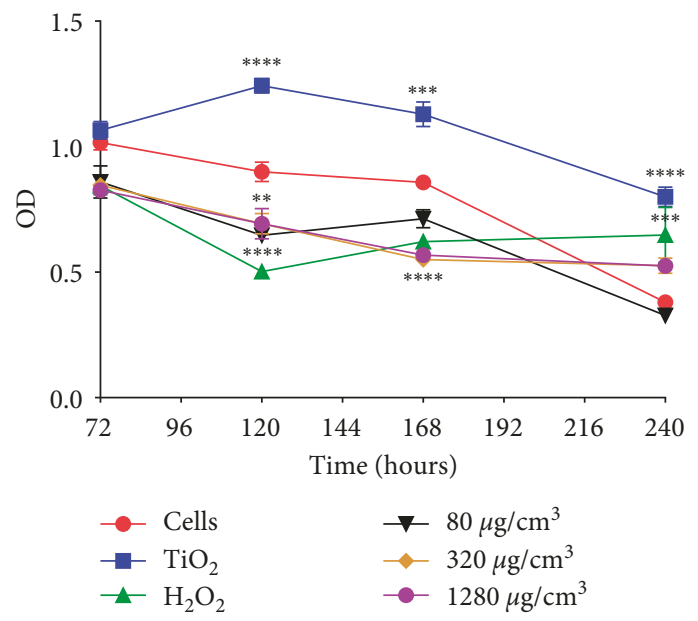

(a)

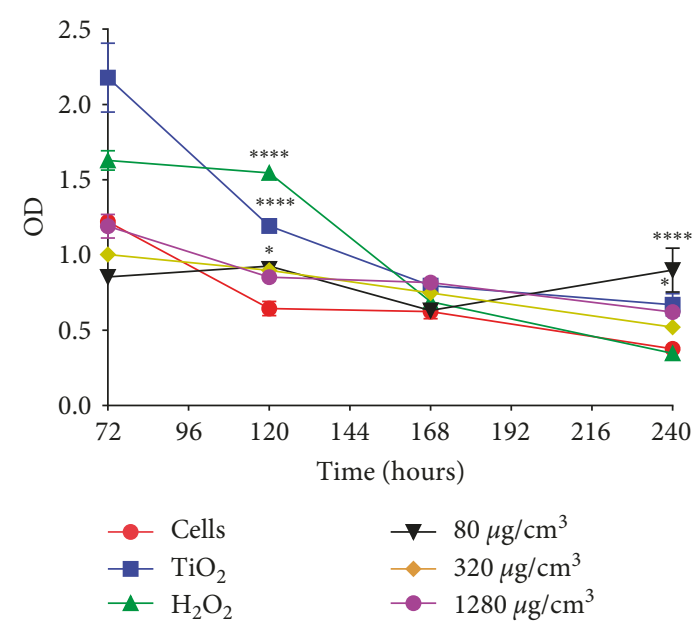

(b)

Figure 6: Cell viability, as assessed by MTT assay, of Pichincha volcanic ash in (a) A549 and (b) McCoy cells with ash treatments after 72, 120,168 , and 240 hours. The monolayer cell cultures were exposed to $80 \mu \mathrm{g} / \mathrm{cm}^{3}$ (black), $320 \mu \mathrm{g} / \mathrm{cm}^{3}$ (yellow), and $1280 \mu \mathrm{g} / \mathrm{cm}^{3}$ (purple) of volcanic ash and $400 \mu \mathrm{g} / \mathrm{cm}^{3}$ titanium dioxide (blue). The negative control (red) was cell without any treatment. ${ }^{*} p<0.05$; ${ }^{* *} p<0.01$ (twoway ANOVA with Dunnett's posttest).

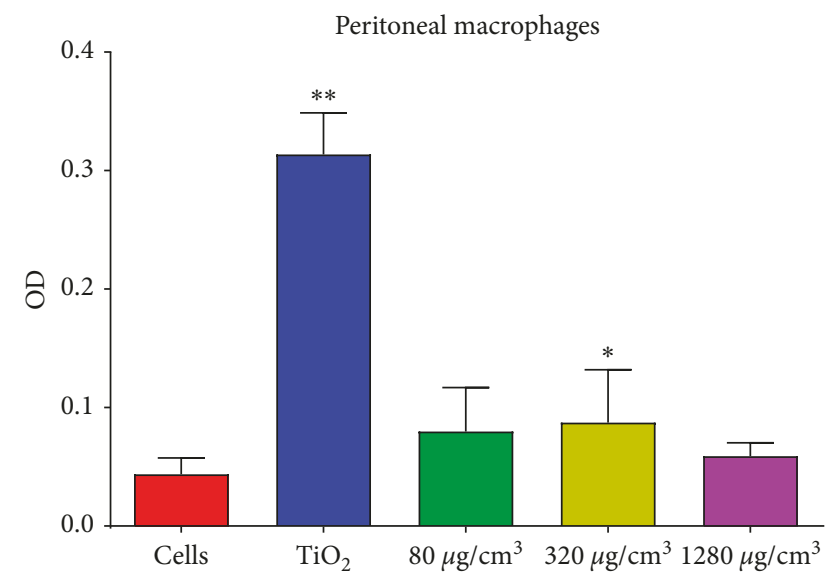

FIGURE 7: Nitric oxide production on peritoneal macrophages by volcanic ash after 24 hours. Macrophages were exposed to $80 \mu \mathrm{g} / \mathrm{cm}^{3}$ (green), $320 \mu \mathrm{g} / \mathrm{cm}^{3}$ (yellow), and $1280 \mu \mathrm{g} / \mathrm{cm}^{3}$ (purple) of volcanic ash and $400 \mu \mathrm{g} / \mathrm{cm}^{3}$ of titanium dioxide (blue). The negative control was cells without any treatment (red). ${ }^{*} p<0.05$; ** $p<0.01$ (one-way ANOVA with Dunnett's posttest).

treatment (Figure 7). The lack of the dose response effect can be justified by the fact that $\mathrm{NO}$ which is normally produced after activation of the macrophage by pathogens, in the case of volcanic ash, the cellular mechanism of activation in macrophages is unknown. However, titanium oxide induced significantly nitric oxide production in macrophages. The study from Kobzik et al. [50] reported a strong inducible NO in rat macrophages after the exposition of LPS by immunostaining, while the control macrophages have been negative. Nonetheless, A549 and McCoy cells did not present statistical difference in NO absorbance. This can be explained by the fact that $\mathrm{NO}$ is a constitutive product. Besides, a fundamental mode of inactivation of $\mathrm{NO}$ is its reaction with superoxide anion $\left(\mathrm{O}_{2}^{-}\right)$to form the potent oxidant peroxynitrite $\left(\mathrm{ONOO}^{-}\right)$[52]. However, results from the hepatocellular carcinoma cell line indicate that the silica NPs may lead to increased cellular reactive oxygen species (ROS) production for 24 hours exposure [47].

3.6.2. Superoxide Dismutases. The superoxide dismutases (SODs) are a family of enzymes that effectively catalyze the dismutation of superoxide anion $\left(\mathrm{O}_{2}{ }^{-}\right)$. The superoxide anion $\left(\mathrm{O}_{2}^{-}\right)$generated in the mitochondria or in the other systems is converted by the SOD into hydrogen peroxide $\left(\mathrm{H}_{2} \mathrm{O}_{2}\right)$, which in turn is also converted into water $\left(\mathrm{H}_{2} \mathrm{O}\right)$ by catalase or glutathione peroxidase (GPx) [53]. Therefore, this antioxidant enzyme is very important to maintain the balance between the production of reactive oxygen species and antioxidants, since it can initiate oxidative chain reactions and lipid peroxidation that cause serious cellular damage [54].

Spectrophotometric studies documented that treatment of A549 cells with volcanic ash indicated a considerable decrease $(<60 \%)$ in superoxide dismutase activity leading to the formation of reactive oxygen species in cells exposed to 80,320 , and $1280 \mu \mathrm{g} / \mathrm{cm}^{3}$ compared to the control cells (Figure 8(a)) in 24 hours. After hydrogen peroxide exposure, the SOD activity has been decreased significantly, reaching $40 \%$ in A549 cells (Figure 8(a)). In contrast to Lu et al. [54] study, the SOD activity has not been statistically altered by lung cells exposed to nano- $\mathrm{SiO}_{2}$ alone compared with control cells.

Similarly, as seen in lung A549 cells, McCoy cells also revealed a statistically significant increase in the formation of ROS when exposed to volcanic ash at a concentration of 80 , 320 , and $1280 \mu \mathrm{g} / \mathrm{cm}^{3}$ for 24 hours (Figure $8(\mathrm{~b})$ ). The activity of the SOD enzyme in McCoy cell line reaches the lowest point $(62 \%)$ in 24 hours where cells have been exposed to $80 \mu \mathrm{g} / \mathrm{cm}^{3}$ (Figure $8(\mathrm{~b})$ ). However, the absence of the dose 


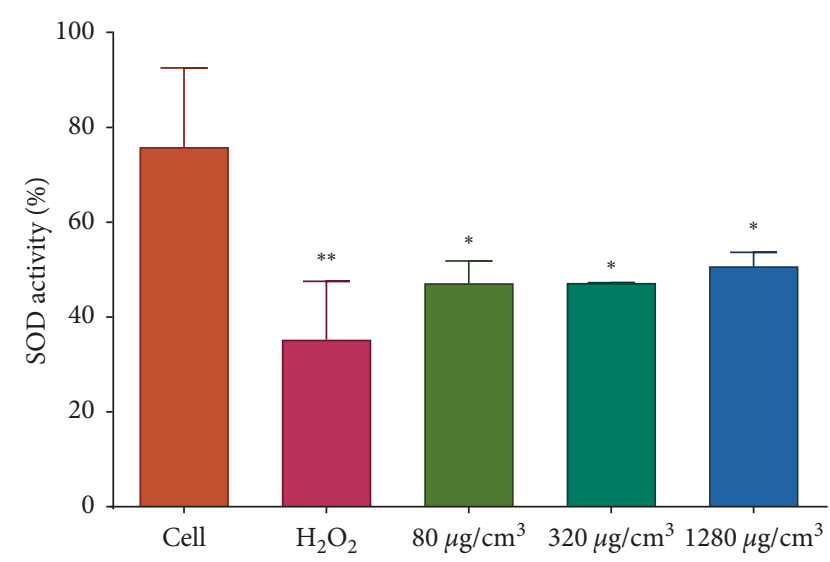

(a)

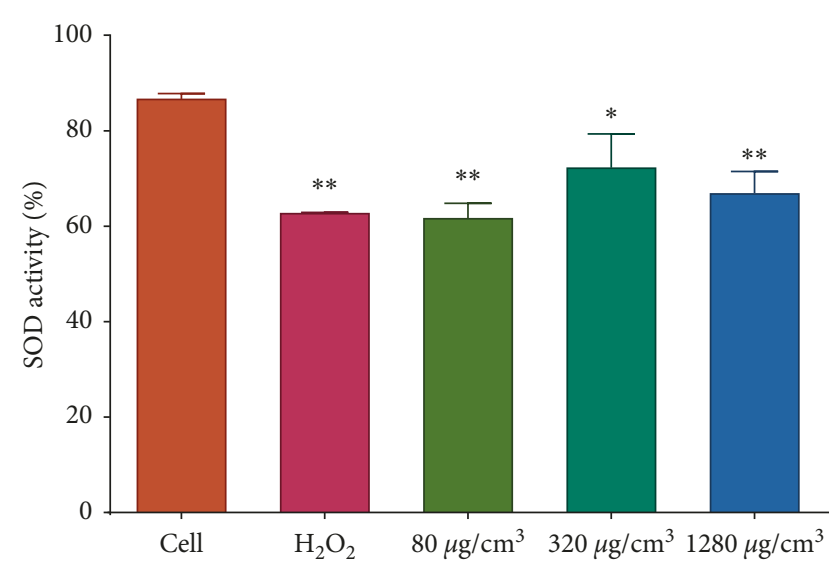

(b)

FIgURE 8: Effect of Pichincha's volcanic ash on the activity of the superoxide dismutase enzyme (SOD) in (a) A549 and (b) McCoy cell lines at 24 hours after treatment with 80,320 , and $1280 \mu \mathrm{g} / \mathrm{cm}^{3}$ of volcanic ash. ${ }^{*} p<0.05{ }^{* *} p<0.01$ (one-way ANOVA with Sidak's post hoc test).

response effect can be explained by the saturation in the secretion of the antioxidant enzyme superóxido dismutasa after volcanic ash exposition.

\section{Conclusions}

The ash of the Pichincha volcano induces an inflammatory response in the murine lung by activating the inflammasome NRLP 3 complex that can precipitate cellular pyrolysis and compromise the health of the animals exposed to this agent evidenced in the change in body weight and mortality. While after the in vitro tests, it is determined that the morphology of the cells changes, there is a reduction in the density, and the vacuolization is evident in peritoneal macrophages. Likewise, the effects of volcanic ash are the marked cellular toxicity dependent on the concentration of ash and the time of exposure and the imbalance of the regulation of reactive oxygen species by deactivating the activity of the antioxidant enzyme. The volcanic ash in peritoneal macrophages is toxic because it induces the production of nitric oxide or is a response to the inflammation produced. It is the first report of the biological effects or impacts produced by the ashes of the Pichincha volcano, so it is the guide to continue with future investigations that will clarify the effect of volcanic ash on Ecuadorian population.

\section{Data Availability}

The data used to support the findings of this study are available from the corresponding author upon request.

\section{Conflicts of Interest}

The authors declare that they have no conflicts of interest.

\section{Authors' Contributions}

Cristina Aguilera and Marco Viteri contributed equally to this work.

\section{Acknowledgments}

This work has been supported by the staff of the National Institute of Public Health Research (INSPI) as well as by the Laboratory of Immunology and Virology at the Universidad de las Fuerzas Armadas ESPE. The authors thank Dr. Alexis Debut and Dr. Carlos Arroyo for the SEM images and analysis at UFA-ESPE. McCoy cells were gently provided by Dr. Judith Torres. The authors thank Dr. Sandeep Kumar from Emory University for proofreading the manuscript.

\section{Supplementary Materials}

Table S1: the detail of chemical composition expressed as mass percent of major elements of 100 ash particles from the ash samples of the 5th of October 1999 eruption of the PVC. (Supplementary Materials)

\section{References}

[1] R. D’Ercole, P. Metzger, and A. Sierra, “Alerta volcánica y erupción del volcán Pichincha en Quito (1998-1999)," Bulletin de l'Institut Français d'Études Andines, vol. 38, no. 3, pp. 487-499, 2009.

[2] Global Volcanism Program, "Report on Guagua Pichincha (Ecuador)," Bulletin of the Global Volcanism Network, vol. 24, no. $12,1999$.

[3] C. Buzea, I. I. Pacheco, and K. Robbie, "Nanomaterials and nanoparticles: sources and toxicity," Biointerphases, vol. 2, no. 4, pp. MR17-MR71, 2007.

[4] M. Monzier, P. Samaniego, C. Robin et al., "Evolution of the Pichincha volcano complex (Ecuador)," in Proceedings of the Fifth International Symposium on Andean Geodynamics, Toulouse, France, September 2002.

[5] M. Alvarez and J. Avilés, Consideraciones Quimicas y Medioambientales 2. Unidad Prep para Desastr Químicos, Ministro Salud Pública, Ecuador, 1999.

[6] B. K. G. Theng and G. Yuan, "Nanoparticles in the soil environment," Elements, vol. 4, no. 6, pp. 395-399, 2008.

[7] M. R. Wilson, V. Stone, R. T. Cullen, A. Searl, R. L. Maynard, and K. Donaldson, "In vitro toxicology of respirable 
Montserrat volcanic ash," Occupational and Environmental Medicine, vol. 57, no. 11, pp. 727-733, 2000.

[8] A. G. Heppleston, "Minerals, fibrosis, and the lung," Environmental Health Perspectives, vol. 94, pp. 149-168, 1991.

[9] V. Vallyathan, M. S. Mentnech, L. E. Stettler, D. D. Dollberg, and F. H. Green, "Mount St. Helens' volcanic ash: hemolytic activity," Environmental Research, vol. 30, no. 2, pp. 349-360, 1983.

[10] N. Fujimura, "Pathology and pathophysiology of pneumoconiosis," Current Opinion in Pulmonary Medicine, vol. 6, no. 2, pp. 140-144, 2000.

[11] A. S. Rodrigues, M. S. C. Arruda, and P. V. Garcia, "Evidence of DNA damage in humans inhabiting a volcanically active environment: a useful tool for biomonitoring," Environment International, vol. 49, pp. 51-56, 2012.

[12] R. Camarinho, P. V. Garcia, and A. S. Rodrigues, "Chronic exposure to volcanogenic air pollution as cause of lung injury," Environmental Pollution, vol. 181, pp. 24-30, 2013.

[13] S. H. Lee and R. J. Richards, "Montserrat volcanic ash induces lymph node granuloma and delayed lung inflammation," Toxicology, vol. 195, no. 2-3, pp. 155-165, 2004.

[14] D. E. Damby, F. A. Murphy, C. J. Horwell, J. Raftis, and K. Donaldson, "The in vitro respiratory toxicity of cristobalite-bearing volcanic ash," Environmental Research, vol. 145, pp. 74-84, 2016.

[15] W. Lin, Y. Huang, X. D. Zhou, and Y. Ma, "In vitro toxicity of silica nanoparticles in human lung cancer cells," Toxicology and Applied Pharmacology, vol. 217, no. 3, pp. 252-259, 2006.

[16] C. J. Horwell, I. Fenoglio, K. Vala Ragnarsdottir, R. S. J. Sparks, and B. Fubini, "Surface reactivity of volcanic ash from the eruption of Soufrière Hills volcano, Montserrat, West Indies with implications for health hazards," Environmental Research, vol. 93, no. 2, pp. 202-215, 2003.

[17] V. Castranova, L. Bowman, J. M. Shreve, G. S. Jones, and P. R. Miles, "Volcanic ash: toxicity to isolated lung cells," Journal of Toxicology and Environmental Health, vol. 9, no. 2, pp. 317-325, 1982.

[18] E. N. Naumova, H. Yepes, K. Griffiths et al., "Emergency room visits for respiratory conditions in children increased after Guagua Pichincha volcanic eruptions in April 2000 in Quito, Ecuador observational study: time series analysis," Environmental Health, vol. 6, no. 1, p. 111, 2007.

[19] V. A. Vaca, R. C. Arroyo, A. Debut, and T. Toulkeridis, "The 2015 volcanic activity of Cotopaxi volcano ash data set," in Proceedings of the Imprenta ESPE, vol. 1, p. 214, Sangolqu1, Ecuador, August-September 2016.

[20] V. A. Vaca, R. C. Arroyo, A. Debut, and T. Toulkeridis, "The 2015 volcanic activity of Cotopaxi volcano ash data set," in Proceedings of the Imprenta ESPE, vol. 2, p. 214, Sangolqui, Ecuador, September 2016.

[21] V. A. Vaca, R. C. Arroyo, A. Debut, and T. Toulkeridis, "The 2015 volcanic activity of Cotopaxi volcano ash data set," in Proceedings of the Imprenta ESPE, vol. 3, p. 210, Sangolqu1, Ecuador, September-October 2016.

[22] V. A. Vaca, R. C. Arroyo, A. Debut, and T. Toulkeridis, "The 2015 volcanic activity of Cotopaxi volcano ash data set," in Proceedings of the Imprenta ESPE, vol. 4, p. 220, Sangolqu1, Ecuador, October-November 2016.

[23] E. J. Park, H. Kim, Y. Kim, J. Yi, K. Choi, and K. Park, "Carbon fullerenes (C60s) can induce inflammatory responses in the lung of mice," Toxicology and Applied Pharmacology, vol. 244, no. 2, pp. 226-233, 2010.

[24] P. Chomzynski and N. Sacchi, "Single-step method of RNA isolation by acid guanidinium thiocyanate-phenol- chloroform extraction," Analytical Biochemistry, vol. 162, no. 1, pp. 156-159, 1987.

[25] E. Yano, A. Takeuchi, S. Nishii et al., "In vitro biological effects of volcanic ash from Mount Sakurajima," Journal of Toxicology and Environmental Health, vol. 16, no. 1, pp. 127-135, 1985.

[26] B. Trouiller, R. Reliene, A. Westbrook, P. Solaimani, and R. H. Schiestl, "Titanium dioxide nanoparticles induce DNA damage and genetic instability in vivo in mice," Cancer Research, vol. 69, pp. 8784-8789, 2009.

[27] M. Ghosh, M. Bandyopadhyay, and A. Mukherjee, "Genotoxicity of titanium dioxide $\left(\mathrm{TiO}_{2}\right)$ nanoparticles at two trophic levels: plant and human lymphocytes," Chemosphere, vol. 81, pp. 1253-1262, 2010.

[28] J. C. Lai, M. B. Lai, S. Jandhyam et al., "Exposure to titanium dioxide and other metallic oxide nanoparticles induces cytotoxicity on human neural cells and fibroblasts," International Journal of Nanomedicine, vol. 2008, no. 4, pp. 533-545, 2008.

[29] J. Zhao, L. Bowman, X. Zhang et al., "Titanium dioxide $\left(\mathrm{TiO}_{2}\right)$ nanoparticles induce JB6 cell apoptosis through activation of the caspase-8/Bid and mitochondrial pathways," Journal of Toxicology and Environmental Health, Part A, vol. 72, no. 19, pp. 1141-1149, 2009.

[30] D. E. Keil, B. Buck, D. Goossens et al., "Health effects from exposure to atmospheric mineral dust near Las Vegas, NV, USA," Toxicol Reports, vol. 3, pp. 785-795, 2016.

[31] M. L. McCaskill, D. J. Romberger, J. DeVasure et al., "Alcohol exposure alters mouse lung inflammation in response to inhaled dust," Nutrients, vol. 4, no. 7, pp. 695-710, 2012.

[32] T. R. Martin, G. Ayars, J. Butler, and L. C. Altman, "The comparative toxicity of volcanic ash and quartz effects on cells derived from the human lung," American Review of Respiratory Disease, vol. 130, no. 5, pp. 778-782, 1984.

[33] T. R. Martin, E. Y. Chi, D. S. Covert et al., "Comparative effects of inhaled volcanic ash and quartz in rats 1-4," American Review of Respiratory Disease, vol. 128, no. 1, pp. 144-152, 1983.

[34] F. Martinon, K. Burns, and J. Tschopp, "The inflammasome: a molecular platform triggering activation of inflammatory caspases and processing of proIL- $\beta$," Molecular Cell, vol. 10, no. 2, pp. 417-426, 2002.

[35] R. Suárez and N. Buelvas, El Inflamasoma: Mecanismos de Activación, Investigación Clínica, Maracaibo, Venezuela, 2015.

[36] C. D. Savage, G. Lopez-Castejon, A. Denes, and D. Brough, "NLRP3-inflammasome activating DAMPs stimulate an inflammatory response in glia in the absence of priming which contributes to brain inflammation after injury," Frontiers in Immunology, vol. 3, p. 288, 2012.

[37] V. Hornung, F. Bauernfeind, A. Halle et al., "Silica crystals and aluminum salts activate the NALP3 inflammasome through phagosomal destabilization," Nature Immunology, vol. 9, no. 8, pp. 847-856, 2008.

[38] K. Schroder and J. Tschopp, "The Inflammasomes," Cell, vol. 140, no. 6, pp. 821-832, 2010.

[39] A. Akhter, K. Caution, A. Abu Khweek et al., "Caspase-11 promotes the fusion of phagosomes harboring pathogenic bacteria with lysosomes by modulating actin polymerization," Immunity, vol. 37, no. 1, pp. 35-47, 2012.

[40] D. J. Lee, F. Du, S. W. Chen et al., "Regulation and function of the caspase-1 in an inflammatory microenvironment," Journal of Investigative Dermatology, vol. 135, no. 8, pp. 20122020, 2015. 
[41] T. T. Huang, K. Y. Chong, D. M. Ojcius et al., "Hirsutella sinensis mycelium suppresses interleukin- $1 \beta$ and interleukin18 secretion by inhibiting both canonical and non-canonical," Scientific Reports, vol. 3, no. 1, p. 1374, 2013.

[42] F. Ethuin, C. Delarche, S. Benslama, M. A. Gougerot-Pocidalo, L. Jacob, and S. Chollet-Martin, "Interleukin-12 increases interleukin 8 production and release by human polymorphonuclear neutrophils," Journal of Leukocyte Biology, vol. 70, no. 3, pp. 439-446, 2001.

[43] T. Ichinose, M. Nishikawa, H. Takano et al., "Pulmonary toxicity induced by intratracheal instillation of Asian yellow dust (Kosa) in mice," Environmental Toxicology and Pharmacology, vol. 20, no. 1, pp. 48-56, 2005.

[44] J. Duan, Y. Yu, Y. Li et al., "Toxic effect of silica nanoparticles on endothelial cells through DNA damage response via Chk1dependent G2/M checkpoint," PLoS One, vol. 8, no. 4, Article ID e62087, 2013.

[45] J. D. Byrne and J. A. Baugh, "The significance of nanoparticles in particle-induced pulmonary fibrosis," McGill Journal of Medicine, vol. 11, no. 1, pp. 43-50, 2008.

[46] S. N. P. Voicu, D. Dinu, C. Sima et al., "Silica nanoparticles induce oxidative stress and autophagy but not apoptosis in the MRC-5 cell line," International Journal of Molecular Sciences, vol. 16, no. 12, pp. 29398-29416, 2015.

[47] L. Sun, Y. Li, X. Liu et al., "Cytotoxicity and mitochondrial damage caused by silica nanoparticles," Toxicology in Vitro, vol. 25, no. 8, pp. 1619-1629, 2011.

[48] M. M. Monick, J. Baltrusaitis, L. S. Powers et al., "Effects of Eyjafjallajökull volcanic ash on innate immune system responses and bacterial growth in vitro," Environmental Health Perspectives, vol. 121, no. 6, pp. 691-698, 2013.

[49] M. V. Berridge and A. S. Tan, "Characterization of the cellular reduction of 3-(4,5-dimethylthiazol-2-yl)-2,5-diphenyltetrazolium bromide (MTT): subcellular localization, substrate dependence, and involvement of mitochondrial electron transport in MTT reduction," Archives of Biochemistry and Biophysics, vol. 303, no. 2, pp. 474-482, 1993.

[50] L. Kobzik, D. S. Bredt, C. J. Lowenstein et al., "Nitric oxide synthase in human and rat lung: immunocytochemical and histochemical localization," American Journal of Respiratory Cell and Molecular Biology, vol. 9, no. 4, pp. 371-377, 1993.

[51] U. Förstermann and W. C. Sessa, "Nitric oxide synthases: regulation and function," European Heart Journal, vol. 33, no. 7, pp. 829-837, 2012.

[52] R. G. Alscher, N. Erturk, and L. S. Heath, "Role of superoxide dismutases (SODs) in controlling oxidative stress in plants," Journal of Experimental Botany, vol. 53, pp. 1331-1341, 2002.

[53] S. Jaramillo, A. Villa, A. F. Pineda, Á. B. Gallego, P. Tabares, and A. Ceballos, "Blood activity of superoxide dismutase and glutathione peroxidase in grazing dairy heifers," Pesquisa Agropecuária Brasileira, vol. 40, no. 11, pp. 1115-1121, 2005.

[54] C. F. Lu, X. Y. Yuan, L. Z. Li et al., "Combined exposure to nano-silica and lead-induced potentiation of oxidative stress and DNA damage in human lung epithelial cells," Ecotoxicology and Environmental Safety, vol. 122, pp. 537-544, 2015. 


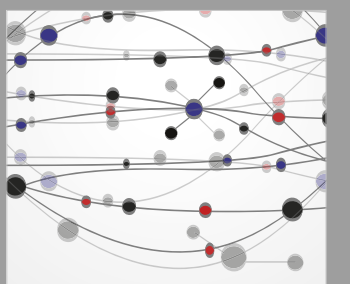

The Scientific World Journal
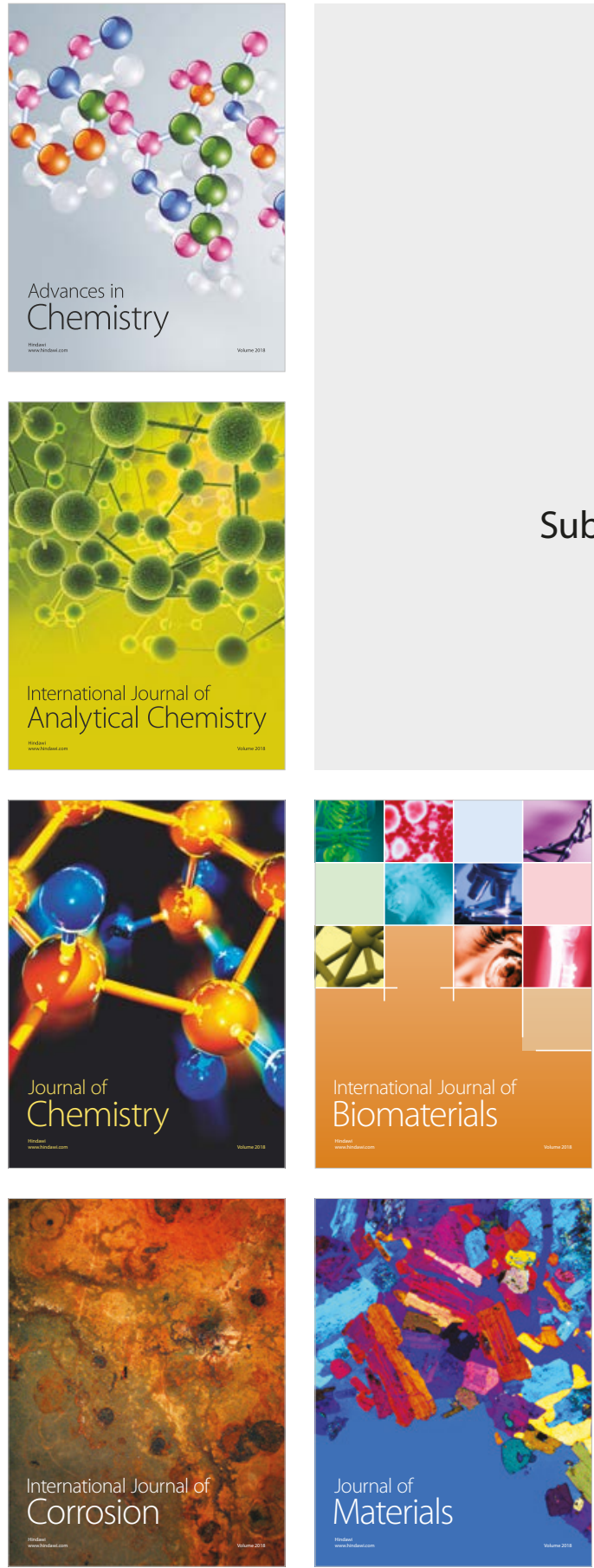

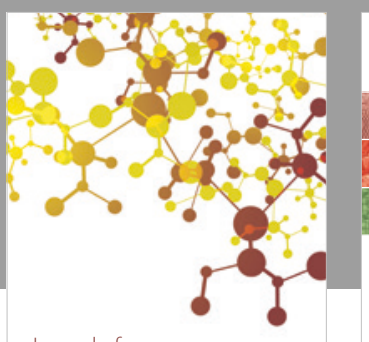

Journal of

Applied Chemistry
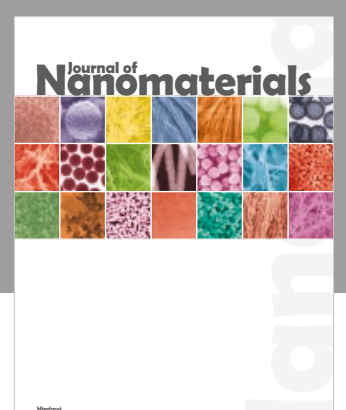

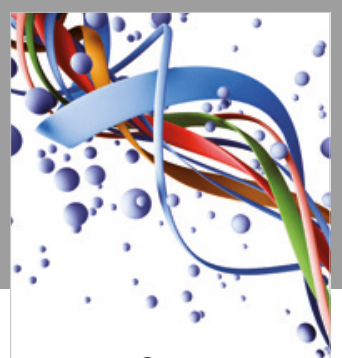

Scientifica

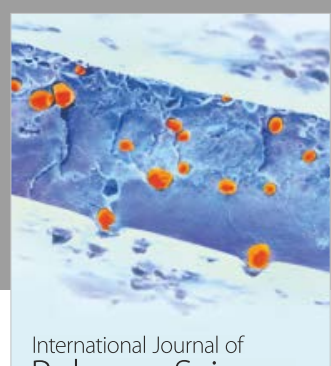

Polymer Science

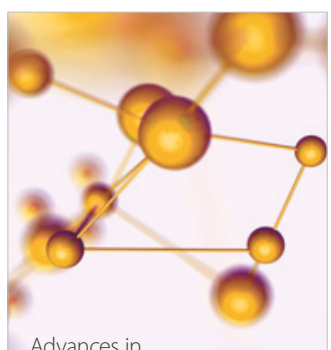

Physical Chemistry
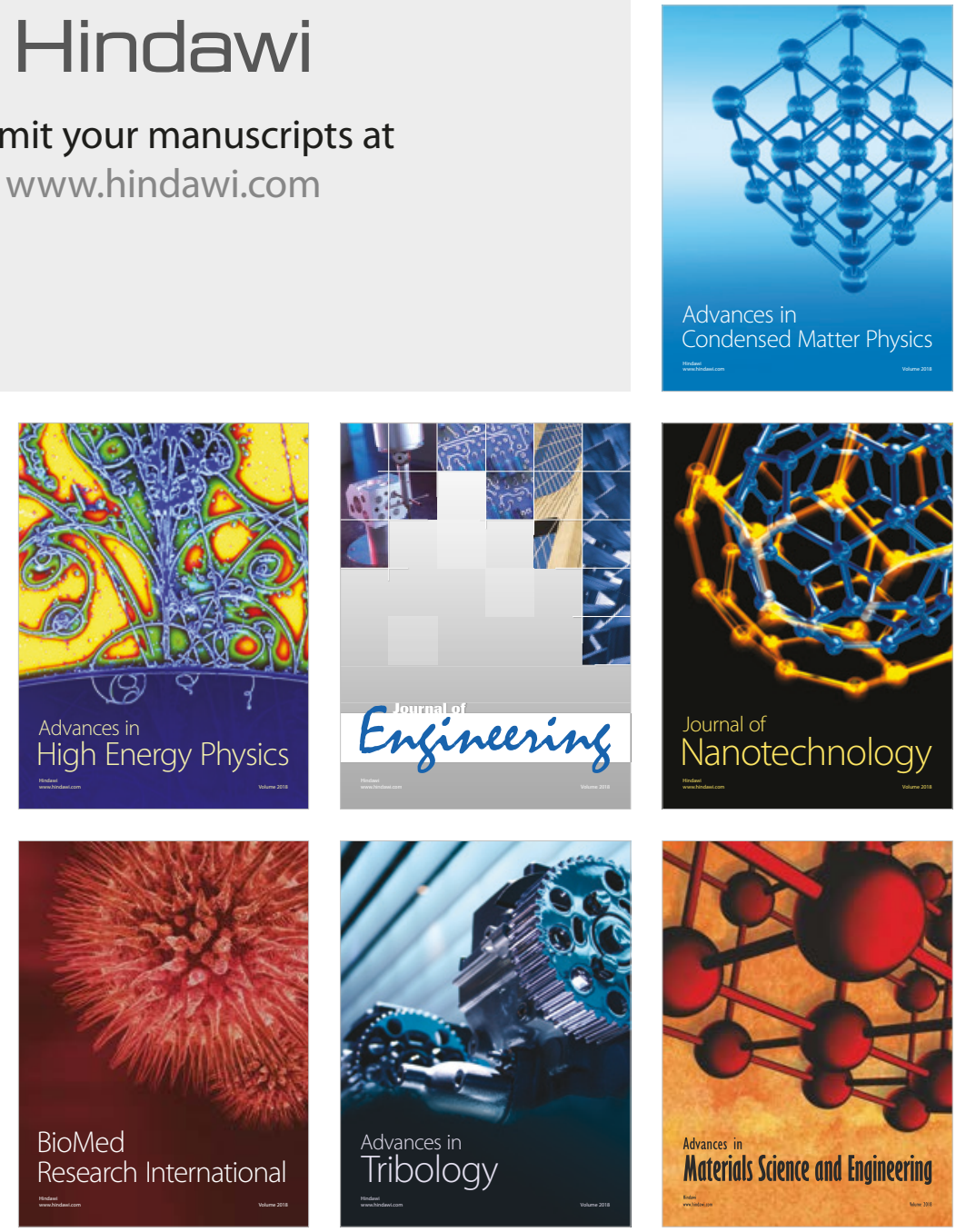